\title{
3 Research S Suare \\ The therapeutic effects of larval excretion/secretion of Lucilia sericata on Leishmania major under in vitro and in vivo conditions
}

\section{Jila Sherafati}

Tarbiat Modares University Faculty of Medical Sciences

Mohammad Saaid Dayer ( $\nabla$ dayer@modares.ac.ir)

Tarbiat Modares University Faculty of Medical Sciences

\section{Fatemeh Ghaffarifar}

Tarbiat Modares University Faculty of Medical Sciences

\section{Research}

Keywords: Leishmania major, Antileishmanial agents, Larval Excretion/Secretion, Lucilia sericata, Maggot therapy, Cutaneous leishmaniasis

Posted Date: December 3rd, 2021

DOI: https://doi.org/10.21203/rs.3.rs-1118263/v1

License: (c) (i) This work is licensed under a Creative Commons Attribution 4.0 International License. Read Full License 


\section{Abstract \\ Background}

Leishmaniasis is a neglected infectious disease caused by a kinetoplastid protozoan. The disease generally manifests as characteristic skin lesions. Due to the lack of definitive treatment and drugs without side effects, many studies have focused on natural compounds as promising drugs for its treatment. This study aimed to evaluate the effects of larval excretion/secretion products (ES) of Lucilia sericata in crude and fractionated forms on Leishmania parasites under both in vitro and in vivo conditions.

\section{Methods}

In vitro experiments involved evaluation of ES products on both promastigotes and amastigotes inside infected macrophages, whereas in vivo experiments included comparative treatments of Leishmanial lesions of mice using Eucerin-formulated ES products and glucantime.

\section{Results}

The $\mathrm{IC}_{50}$ values were $38.7 \mu \mathrm{g} / \mathrm{ml}, 47.6 \mu \mathrm{g} / \mathrm{ml}, 63.3 \mu \mathrm{g} / \mathrm{ml}$, and $29.1 \mu \mathrm{g} / \mathrm{ml}$ for crude ES, over $10 \mathrm{kDa}$ ESfraction, under $10 \mathrm{kDa}$ ES-fraction, and glucantime respectively. Significant differences were observed between viability percentages of promastigotes treated with crude ES and its fractions compared to negative control $(p<0.0001)$. Crude ES was more effective on amastigote than other two ES fractions at $300 \mu \mathrm{g} / \mathrm{ml}$ concentration. Macroscopic measurement of lesion sizes revealed that the reduction of lesion size in mice treated with crude ES followed quicker cascades of healing than in those treated with glucantime and fractionated ES.

\section{Conclusion}

The present study showed that larval ES of Lucilia sericata in both crude and fractionated forms are effective on both intracellular and extracellular forms of $L$. major. It also provided evidence that the larval ES exerts both topical and systemic therapeutic effects on leishmanial lesions of the model animal.

\section{Introduction}

Leishmaniasis is a neglected tropical disease caused by protozoan Leishmania spp. It is estimated that approximately 350 billion people who live in endemic areas are at risk of various forms of leishmaniasis [1]. About 20 species of Leishmania are known to be capable of infecting humans and a range of animals, causing one of three clinical forms in humans called visceral leishmaniasis (VL), cutaneous leishmaniasis (CL), and mucosal cutaneous leishmaniasis (MCL) [2]. Infected bites of Phlebotomus and 
Lutzomyia female sandflies are the main route of transmission of Old World and New World leishmaniasis respectively [3].

$\mathrm{CL}$ is the most common form of the disease which causes disfiguring skin lesions with life-long scars on the hands and face [4]. Globally, leishmaniasis imposes a great deal of disability-adjusted life years (DALYs) and economic loss each year [5]. In endemic areas, abundance of sand fly vectors, expensive drugs, long treatment time and parasite drug resistance are among serious setbacks for the control of the disease $[6,7]$. In addition to the side effects of medications, the post-treatment ugly scars of CL leave unaesthetic stigma especially in children especially in girls [8]. So far, glucantime, pentamidine and amphotericin B remains the first line treatments of $C L$. To be effective, the drugs need frequent and painful injections. However, upon prolonged use, the drugs may associate with clinical complications such as cardiac arrhythmia and anemia, and even toxicity and renal failure [9, 10,11]. Given these problematics, alternative therapies have recently been suggested for $\mathrm{CL}$ treatment. These include the use of insect-derived natural compounds such as maggot derived products which showed wound healing effects $[12,13]$.

Maggot debridement therapy (MDT) has been widely used in treating chronic wounds. MDT has been successfully used to treat necrotizing fasciitis, perianal gangrene, surgery wounds, burns, venous, arterial and diabetic foot ulcers $[14,15]$. The maggots of Lucilia sericata (Diptera: Calliphoridae) are usually used for MDT $[16,17]$. These maggots exert a combination of wound debridement and disinfection as well as accelerated wound healing by secreting various enzymes for instance proteases and nucleases, antimicrobial peptides (AMPs) and small active molecules $[13,18,19]$. Since its emergence 20 years ago, MDT is increasingly recognized as a promising alternative therapy for wound healing which results not only in efficient wound debridement but also in risk reduction of post-surgery infections [14, 20, 21]. Nowadays, MDT has received approval as a medical device in many countries including USA (FDA, 2004, case number K033391) [22].

The larval excretion/secretion product (ES) of Lucilia sericata has exhibited antimicrobial activity against both the gram-positive and gram-negative bacteria [21,23], as well as against protozoan agents of $\mathrm{CL}$ $[24,25]$. In the present study, the effects of crude and fractionated ES of L. sericata were comparatively investigated against Leishmania major parasite both in in vitro and in vivo conditions. Also, in a bid to find an alternative treatment for CL ulcers, the ES was formulated and tested against leishmanial lesions of infected mice.

\section{Materials And Methods}

\section{Collection and rearing of L. Sericata}

Wild adults of $L$. sericata were collected using bottle traps baited with raw chicken wings and liver in suburban areas of Saqqez City in Kurdistan Province in Iran during a period between May to July 2020. The adult flies were anaesthetized with cold shock and morphologically identified using a morphological key [26]. The fly colony was reared in mesh cages $(60 \times 60 \times 60 \mathrm{~cm})$ at the Insectarium of Medical 
Entomology Department of Tarbiat Modares University under $25 \pm 1{ }^{\circ} \mathrm{C}, 60 \pm 5 \%$ relative humidity and 16 : $8 \mathrm{~h}$ light/dark cycle conditions [25]. Milk powder and sugar water solution (1: 1 ratio) were supplied to feed the adults. Egg harvesting was performed by placing 150_200 gram of fresh beef liver in the rearing cage for $24 \mathrm{~h}$ to allow oviposition [27].

\section{ES collection and sterilization}

About 100 stage II and III larval of $L$. sericata were collected from established colonies. The larval were starved for $6 \mathrm{~h}$ before being washed with $0.5 \%$ sodium hypochlorite and further with $5 \%$ formaldehyde and finally rinsed twice with sterile saline solution in a $50 \mathrm{ml}$ Falcon tube for 5 minutes [28].

Subsequently, $1 \mathrm{ml}$ of saline solution was added to the larvae; the tube was covered with aluminium foil and incubated at $37^{\circ} \mathrm{C}$ for $1 \mathrm{~h}$ [28]. The larval ES were then collected by centrifuged at $4000 \mathrm{rpm}$ for 10 minutes [29].

\section{Bradford assay for protein measurement}

The Bradford Assay Kit was used as a quick and ready-to-use colorimetric method for measuring the total protein of ES. The amount of protein in the solution was measured using a standard curve obtained based on a dilution series of known protein concentrations $(0,31.25,62.5,125,250,500,1000 \mu \mathrm{g} / \mathrm{ml})$. The protein samples were assayed using 7-well plates. The plates were incubated at $+25^{\circ} \mathrm{C}$ for 10 minutes in a dark place. Subsequently, optical absorption was read using an ELISA reader (Model 680, BIORAD Co.) at a wavelength of $570 \mathrm{~nm}$ [30].

\section{Fractionation of larval ES}

Separation of larval ES fractions into two cutoffs of $>10$ and $<10 \mathrm{kDa}$ was performed using Amicon ultra4 centrifugal Filer Unit by centrifugation at $7500 \mathrm{~g}$ for 40 minutes. The isolated fractions and crude ES were passed through $0.22 \mu \mathrm{m}$ syringe filter for sterilization. The ES products were kept at $-20^{\circ} \mathrm{C}$ until used.

\section{L. major culture conditions}

L. majorstrain MRHO/IR/75/ER was maintained by regular passage through Balb/c mice. The amastigotes were isolated from lesions of infected Balb/c mice and transformed to promastigotes on NNN medium. The promastigotes were then cultured in RPMI 1640 medium (Gibco, USA) supplemented with $10 \%$ heat-inactivated fetal bovine serum (FBS) (Gibco, USA) and $100 \mu \mathrm{g} / \mathrm{ml}$ penicillin-streptomycin (Thermo Fisher Scientific, USA). Promastigotes were grown in cell culture flasks. The flasks were incubated at $26^{\circ} \mathrm{C}$ until reaching the desired quantity.

\section{Cell line culture}

The mouse macrophage cell line (J774A.1) was obtained from Pasteur Institute in Tehran. The cells were cultured in DMEM (Gibco, USA) supplemented with 10\% heat-inactivated fetal bovine serum (FBS) (Gibco, 
USA) and $100 \mu \mathrm{g} / \mathrm{ml}$ penicillin-streptomycin (Thermo Fisher Scientific, USA) at $37^{\circ} \mathrm{C}$ in a humidified $5 \%$ $\mathrm{CO}_{2}$ incubator.

\section{Promastigote assay}

Promastigotes of L. major were cultured in RPMI culture medium supplemented with 20\% FBS in 96-well plates at $1 \times 10^{6} \mathrm{cell} / \mathrm{ml}$ concentration. A serial dilution was prepared from crude and fractionated ES at initial concentration of $350 \mathrm{mg} / \mathrm{ml}$ using RPMl-1640 medium. The ES dilutions were used to treat promastigotes aliquoted in 96-well plates. Promastigotes cultured in the same medium with no drug added were used as a negative control. Each test was done in triplicate and the plates were incubated at $26^{\circ} \mathrm{C}$. In order to evaluate the parasite survival, the multiplication of the promastigotes was determined by counting the cells using a hemocytometer slide (Neubauer chamber) after 24,48 and $72 \mathrm{~h}$ of incubation [31].

\section{Cytotoxicity assay by MTT method}

Macrophage cells (J774A.1 cell line) were cultured in DMEM medium containing $10 \% \mathrm{FBS}$ at $37^{\circ} \mathrm{C}$ under $5 \% \mathrm{CO}_{2}$ atmosphere [32]. The macrophages at $10^{5} \mathrm{cell} / \mathrm{ml}$ concentration were aliquoted in each well of a 96-well plate. The wells were filled with various ES concentrations and incubated for $24 \mathrm{~h}$ at $37^{\circ} \mathrm{C}$ under $5 \% \mathrm{CO}_{2}$ atmosphere. Then, $20 \mu \mathrm{l}$ of MTT solution (final concentration of $5 \mathrm{mg} / \mathrm{ml}$ ) was added. The plates containing macrophages and crude and fractionated ES dilutions were incubated for $3-5 \mathrm{~h}$ at $37^{\circ} \mathrm{C}$ before top liquids being removed from the wells. Then, $100 \mu$ of DMSO was added to each well. After 15 min, optical absorption was read using an ELISA reader (Model 680, BIORAD Co.) at a wavelength of 570 $\mathrm{nm}$. The cell survival was measured using the following equation:

Survival rate $=(A T-A B) /(A C-A B) \times 100$

Where;

$A B=$ the optical absorption of the blank,

$A C=$ the optical absorption of the control and

AT $=$ the optical absorption of the treated cell.

\section{Amastigotes assay}

Twelve-well plates were seeded with macrophage cells at $2 \times 10^{6} \mathrm{cells} / \mathrm{ml}$ concentration after a sterile coverslip was placed at the bottom of each well. The plates were incubated at $37^{\circ} \mathrm{C}$ for $24 \mathrm{~h}$ before being infected with $L$. major promastigotes at 10 parasite/macrophage ratio. The infected plates were then incubated for further $24 \mathrm{~h}$ at $37^{\circ} \mathrm{C}$ under $5 \% \mathrm{CO}_{2}$ atmosphere. Free promastigotes were washed out of wells with PBS and a series of concentrations of 1) crude ES (150-300 $\mu \mathrm{g} / \mathrm{ml}), 2)$ ES $>10 \mathrm{kDa}(150-300$ $\mu \mathrm{g} / \mathrm{ml})$, 3) $\mathrm{ES}<10 \mathrm{kDa}(150-300 \mu \mathrm{g} / \mathrm{ml})$, and 4) glucantime $(50-100 \mu \mathrm{g} / \mathrm{ml})$ were added to the plates based on $\mathrm{IC}_{50}$ values obtained in the earlier promastigote assays. The 5 th group of plates received no 
treatment as a negative control. After $72 \mathrm{~h}$ incubation, the coverslips inside the wells were fixed with methanol, stained with $10 \%$ Giemsa and examined by light microscopy. The number of infected macrophages and the average number of parasites per macrophage were counted per 100 cells [31].

\section{Animal ulcers treatment}

Thirty female Balb/c mice (4-6 week old) were obtained from Razi Vaccine and Serum Research Institute (Karaj- Iran). The mice were divided in six groups, each consisting of five animals. Each group was kept in a separate cage, fed ad libitum in the stress-free Animal House of Tarbiat Modares University.

Logarithmic phase $L$. major promastigotes were used to prepare an inoculum containing $2 \times 10^{6}$ cells at a final volume of $100 \mu \mathrm{l} / \mathrm{ml}$ for subcutaneous injection of each mouse at the base of its tail. Injections were performed by insulin syringes under an aseptic laminar air flow cabinet. Lesions were development after 5 weeks' post-inoculation when lesion treatment started by topical application of ES products. The lesion size was measured before and after treatment and used as an indication for wound healing. The weekly measurement of the lesion sizes was continued for further four weeks.

\section{ES preparation for ulcers treatment}

The crude ES and its fractions $(300 \mu \mathrm{g} / \mathrm{ml})$ were combined separately with Eucerin at a ratio of $(1: 1)$ to obtain formulated ointments for lesion treatment. The first group of infected mice was treated with an ointment formulated with the crude ES, the second group with ES fraction $>10 \mathrm{kDa}$ and third group with ES fraction $<10 \mathrm{kDa}$. The fourth group was treated with glucantime as positive control and the fifth group kept without treatment as negative control. Finally, the sixth group was treated with pure Eucerin to evaluate its possible impact on lesion treatment. All medications were prepared on the daily basis before application.

\section{Parasite load evaluation}

Eight weeks after lesion treatment, two mice of each treated group were dissected to estimate the parasitic load in their spleens. To this end, a piece of each spleen was mixed with $500 \mu \mathrm{lRPMI}$ medium. Then, $50 \mu \mathrm{l} / \mathrm{ml}$ of the mixture was transferred to a 96-well plate containing complete medium enriched with $20 \%$ FBS. The plates were incubated at $26^{\circ} \mathrm{C}$ for 10 days. Each test was performed in triplicate. Fifteen serial dilutions were prepared for all five mice groups. Then, the total number of positive wells (presence of motile promastigotes) and negative wells (absence of motile promastigotes) was identified by an inverted light microscope [33].

\section{Statistical analyses}

Experimental results were analyzed with T-test, and one-way ANOVA using GraphPad Prism version 6.07. To determine the independence of two categorical variables Chi-square and/or Fisher's exact tests were also undertaken. The data was presented as means \pm standard deviation (SD). Dose-response curves were drawn using non-linear regression. Bradford equation was obtained through online software at (https://www.aatbio.com) and the graph was plotted using Prism. Amastigote susceptibility to ES was analyzed using the equations presented in [34]. The difference was considered significant at $P<0.05$. 


\section{Results}

\section{Bradford assay}

As depicted in Figure 1, there was a linear relationship between protein concentrations and the read OD's which were used to calculate the linear equation and therefore the protein concentrations of ES samples. Given the average net absorbance values at $595 \mathrm{~nm}$ for three samples of Crude ES, ES >10 kDa and ES $<10 \mathrm{kDa}$ were $1.69,1.53$ and 1.151 respectively, the average protein concentrations of the samples were $885.92,731.80$ and $366.71 \mu \mathrm{g} / \mathrm{ml}$ respectively (Figure 1). Therefore, the maximum protein concentration of ES samples used in this study was set at $350 \mu \mathrm{g} / \mathrm{ml}$.

\section{Sensitivity of promastigotes to ES}

The $\mathrm{IC}_{50}$ values of larval ES of $L$. sericata were evaluated against parasite promastigotes at 24,48 and 72 h. The lowest IC $\mathrm{I}_{50}$ values for crude ES, ES $>10 \mathrm{kDa}$ and ES $<10 \mathrm{kDa}$ were $38.70 \mu \mathrm{g} / \mathrm{ml}(\mathrm{log}=1.588), 46.48$ $\mu \mathrm{g} / \mathrm{ml}(\log =1.667)$ and $60.44 \mu \mathrm{g} / \mathrm{ml}(\log =1.802)$ at $72 \mathrm{~h}$ respectively. The results were compared with those of glucantime (Figure 2). Statistically significant differences in the viability percentage of promastigotes were observed for crude ES, ES $>10 \mathrm{kDa}$ and ES $<10 \mathrm{kDa}$ at different doses compared with the negative control $(p \leq 0.0001)$. In addition, there were a significant difference in the viability percentage of promastigotes treated with $\mathrm{ES}<10 \mathrm{kDa}$ with glucantime $(p=0.0001)$ but this was not true with crude ES and ES $>10 \mathrm{kDa}$ ( $p$ values equal to 0.8408 and 0.8634 respectively). It was obvious that higher concentrations of ES and longer exposure times lead to greater toxicity to promastigotes. Therefore, the toxic effect of ES was both dose- and time-dependent. Figure 3 illustrates the number of live promastigotes observed directly by light microscopy.

\section{Cytotoxicity assay}

MTT assays showed that crude ES of L. sericata and glucantime have dose-dependent cytotoxic effects to J774A.1 cells $(p<0.0001)$ (Figure $4 a)$ and both exerted higher toxicity to the same cells than ES fractions. In fact, ES fractions induced similar mild effects on the viability percentage of J774A.1 cells with no significant difference among them $(p=0.3425)$ (Figure $4 b)$.

\section{Amastigote susceptibility to larval ES fractions of L. sericata}

Table 1 indicates that infection rates of macrophage cells and percentage of viable amastigotes considerably reduced upon treatment with larval ES fractions for $72 \mathrm{~h}$ compared to the control group ( $p=$ 0.0012 and $p=0.0004$, respectively). The reduction in macrophage infection rates induced by $\mathrm{ES}>10 \mathrm{kDa}$ and $\mathrm{ES}<10 \mathrm{kDa}$ was similar $(p=0.4763)$ but significantly lower than that caused by glucantime $(p=$ 0.015 and $p=0.007$, respectively). However, crude ES and glucantime were similarly effective in reducing macrophage infection rates so that the difference between them was not statistically significant $(p=$ 0.7486). In addition, no difference was observed between the mean number of amastigotes per an 
infected macrophage cell upon treatment with $\mathrm{ES}>10 \mathrm{kDa}$ and $\mathrm{ES}<10 \mathrm{kDa}(p=0.290)$, but the ES fractions were significantly less effective in reducing the number of amastigotes in macrophages than glucantime ( $p=0.029$ and $p=0.010$, respectively). In this respect, the crude ES and glucantime exerted similar effects $(p=0.7890)$. The results showed that the treatment with the crude ES at higher concentrations reduces the infection rate of macrophages and the viability of amastigotes $(p=0.0357)$. The treatment with the crude ES at $300 \mu \mathrm{g} / \mathrm{ml}$ concentration lead to a significant reduction of the parasite load in macrophages equal to $1.75 \pm 0.05$ per cell compared with the negative control treatment. The positive treatment with glucantime at $50 \mu \mathrm{g} / \mathrm{ml}$ concentration also reduced the parasite load to a level of $1.96 \pm 0.07$ amastigote per cell. The survival index of amastigotes recorded the lowest value equal to $53.72 \pm 2.44$ upon treatment with the crude ES at $300 \mu \mathrm{g} / \mathrm{ml}$ concentration (Table 1 and Figure 5).

Table 1

Parameters indicative of L. major amastigote viability and infectivity to J774A.1 under treatments with the crude and fractionated larval ES as well as glucantime.

\begin{tabular}{|c|c|c|c|c|c|}
\hline Treatment & $\begin{array}{l}\text { Dosages } \\
(\mu \mathrm{g} / \mathrm{ml})\end{array}$ & $\begin{array}{l}\text { Infected } \\
\text { cells }^{a}\end{array}$ & $\begin{array}{l}\text { Viability of } \\
\text { amastigotes }^{a}\end{array}$ & $\begin{array}{l}\text { Parasite } \\
\text { load }\end{array}$ & $\begin{array}{l}\text { Survival } \\
\text { index }\end{array}$ \\
\hline Control & 0 & $\begin{array}{l}85.37 \pm \\
3.58\end{array}$ & $100 \pm 0.00$ & $3.19 \pm 0.01$ & $\begin{array}{l}270.9 \pm \\
1.15\end{array}$ \\
\hline \multirow[t]{2}{*}{ Crude ES } & 150 & $\begin{array}{l}41.66 \pm \\
1.28\end{array}$ & $30.27 \pm 1.93$ & $1.97 \pm 0.02$ & $\begin{array}{l}82.23 \pm \\
2.35\end{array}$ \\
\hline & 300 & $\begin{array}{l}32.00 \pm \\
2.43\end{array}$ & $20.58 \pm 2.74$ & $1.75 \pm 0.05$ & $\begin{array}{l}53.72 \pm \\
2.44\end{array}$ \\
\hline \multirow[t]{2}{*}{$\mathrm{ES}>10 \mathrm{kDa}$} & 150 & $\begin{array}{l}58.33 \pm \\
2.75\end{array}$ & $49.90 \pm 2.71$ & $2.28 \pm 0.03$ & $\begin{array}{l}132.99 \pm \\
2.01\end{array}$ \\
\hline & 300 & $\begin{array}{l}51.00 \pm \\
1.55\end{array}$ & $39.46 \pm 3.42$ & $2.10 \pm 0.01$ & $\begin{array}{l}107.33 \pm \\
2.51\end{array}$ \\
\hline \multirow[t]{2}{*}{ ES $<10 \mathrm{kDa}$} & 150 & $\begin{array}{l}62.66 \pm \\
2.38\end{array}$ & $59.93 \pm 2.86$ & $2.60 \pm 0.10$ & $\begin{array}{l}162.73 \pm \\
2.10\end{array}$ \\
\hline & 300 & $\begin{array}{l}55.00 \pm \\
3.10\end{array}$ & $49.02 \pm 3.53$ & $2.42 \pm 0.00$ & $\begin{array}{l}133.21 \pm \\
2.38\end{array}$ \\
\hline \multirow[t]{2}{*}{ Glucantime } & 50 & $\begin{array}{l}39.66 \pm \\
2.08\end{array}$ & $28.54 \pm 0.561$ & $1.96 \pm 0.07$ & $\begin{array}{l}77.67 \pm \\
1.53\end{array}$ \\
\hline & 100 & $\begin{array}{l}30.85 \pm \\
1.53\end{array}$ & $15.51 \pm 1.12$ & $1.68 \pm 0.02$ & $\begin{array}{l}51.01 \pm \\
2.01\end{array}$ \\
\hline
\end{tabular}

\section{Effect of larval ES fractions on leishmanial lesions}

Cutaneous lesions in all infected mice began with redness and swelling at the site of inoculation in the third week post-infection. The swelling increased gradually, crust formation occurred and gangrene 
infection started to develop in the fourth week. The mean lesion size measurements are presented in Table 2. The results of the lesion size measurement showed that the mean lesion sizes in control mice increased progressively to $12.8 \pm 2.86 \mathrm{~mm}^{2}$ until the fourth week post-inoculation. Likewise, the size of wounds increased in Eucerin-treated mice to reach $12 \pm 1.87 \mathrm{~mm}^{2}$ for the same period. In other words, no statistically significant difference was observed between the lesion sizes in control and Eucerin groups ( $p$ $=0.7824)$. This shows that Eucerin has no therapeutic effect by its own. In contrast, the lesion sizes started to decrease gradually in groups treated with ES. The mean lesion sizes were $2.6 \pm 1.19 \mathrm{~mm}^{2}$ in the crude ES-treated group, $5 \pm 2.35 \mathrm{~mm}^{2}$ in ES $>10 \mathrm{kDa}$-treated group, $5.2+2.280 \mathrm{~mm}^{2}$ in ES $<10 \mathrm{kDa}$ treated group and $2.2 \pm 1.327 \mathrm{~mm}^{2}$ in glucantime-treated group. While the crude ES and glucantime were similarly effective in reducing the lesion sizes with no significant difference between them $(p=0.4899)$, both showed significant differences with ES >10 kDa and ES <10 kDa $(p<0.0001)$ in the same respect. In fact, the latter treatments were similarly less effective against lesion development recording no significant difference in reducing lesion sizes $(p=0.7472)$.

Table 2

The effects of the crude and fractionated ES at $300 \mu \mathrm{g} / \mathrm{ml}$ on lesion sizes of Leismania infected mice against positive and negative controls at different time interval postinfection.

\begin{tabular}{|llllll|}
\hline Groups & Initials Lesion & \multicolumn{4}{c|}{ Post-treatment Lesion size $\left(\mathrm{mm}^{2}\right)^{\mathrm{a}}$} \\
\cline { 3 - 6 } & size $\left(\mathrm{mm}^{2}\right)^{\mathrm{a}}$ & 1st week & 2nd week & 3rd week & 4th week \\
\hline Crude ES & $7.6 \pm 2.61$ & $6.6 \pm 2.50$ & $4.8 \pm 2.59$ & $3.8 \pm 2.05$ & $2.6 \pm 1.82$ \\
\hline ES $>10 \mathrm{kDa}$ & $7.4 \pm 2.07$ & $7.2 \pm 1.92$ & $6.4 \pm 1.82$ & $5.8 \pm 1.92$ & $5 \pm 2.35$ \\
\hline ES $<10 \mathrm{kDa}$ & $6.6 \pm 2.05$ & $6.4 \pm 2.30$ & $5.8 \pm 2.77$ & $5.4 \pm 2.30$ & $5.2 \pm 2.28$ \\
\hline Glucantime & $6.8 \pm 1.72$ & $6.4 \pm 2.15$ & $4.8 \pm 1.72$ & $3.6 \pm 1.74$ & $2.2 \pm 1.33$ \\
\hline Eucerin & $7.4 \pm 1.82$ & $8.4 \pm 1.80$ & $9.4 \pm 1.86$ & $10.6 \pm 1.72$ & $12 \pm 1.87$ \\
\hline Control & $7 \pm 2$ & $8.2 \pm 1.92$ & $9.6 \pm 2.30$ & $11.2 \pm 2.77$ & $12.8 \pm 2.86$ \\
\hline a Mean $\pm S D$ & & & & & \\
\hline
\end{tabular}

After the termination of treatment period, the measurement of lesion size was continued for further weeks to assess the possibility of recurrence. A slight increase of lesion sizes was observed in the case of the crude ES-treated $\left(3.0 \pm 2.55 \mathrm{~mm}^{2}\right)$ and glucantime-treated $\left(2.6 \pm 1.96 \mathrm{~mm}^{2}\right)$ groups. Whereas the wounds erupted in mice upon the cessation of treatments with $\mathrm{ES}>10 \mathrm{kDa}\left(6.6 \pm 3.78 \mathrm{~mm}^{2}\right)$ and $\mathrm{ES}<10 \mathrm{kDa}(7 \pm$ $3.39 \mathrm{~mm}^{2}$ ) (Figure 6).

\section{Parasite loads}


The spleen parasite load of mice infected with L. major was determined using the parasite-limiting dilution assay. The parasite load was significantly reduced in treated groups compared with the negative control group $(p<0.0001)$. The latter group showed no significant difference with the Eucerin-treated groups $(p>0.05)$. The crude ES-treated group had the lowest level of parasite load among all treated group with significant difference with others $(p<0.0001)$ except with glucantime treated group $(p=$ 0.2666). As usual, there was no statistically significant difference between groups treated with $E S>10$ $\mathrm{kDa}$ and $\mathrm{ES}<10 \mathrm{kDa}(p=0.0104)$ (Figure 7).

\section{Mice mortality during study phases}

The mortality of experimental mice was monitored from the beginning of treatments until 20 weeks' posttreatments. Mortality in the negative control and Eucerin treated mice started after the seventh week postinfection with sharp rate so that all mice were dead by week 13th post-infection. Whereas, in treated mice, mortality was observed to occur after week 13 th post-infection so that more than $60 \%$ of mice were alive by the end of week 20th. The mortality in the negative control and Eucerin treated groups were similar with no significant difference between them $(p=0.8134)$. However, both differed significantly from other treated group in term of mortality rates $(p<0.0001)$. The lowest mortality rate was observed among the crude ES treated group, however, its difference with glucantime-treated group was not significant $(p=0.2396)$. By the end of 20th week post-infection the survival rates of mice treated with the $E S>10 \mathrm{kD}$ and $\mathrm{ES}<10 \mathrm{kDa}$ were recorded alike at $20 \%$ with no significant difference among the groups $(p=0.3461)$, though they differed significantly with the crude ES and glucantime treated groups $(p<0.0001)$ (Figure 8).

\section{Discussion}

Leishmaniasis continues to colonize new regions in many parts of the words due partly to climate changes which allows wide dispersal of both its sand fly vectors and animal hosts. The most prevalent clinical form of the disease, the cutaneous leishmaniasis is increasingly becoming irresponsive to pentavalent antimonial drugs incurring costly, painful and long-lasting cure which usually leaves ugly scars [35]. Therefore, the search for new remedies for the disease particularly among natural products has gained momentum across the world. Many studies have examined the cytotoxic effects of larval excretion/secretion of various flies including $L$. sericata against different Leishmania species both under in vitro and in vivo conditions $[25,35,36]$. The present study evaluated the anti-leishmanial activity of the crude and fractionated ES of $L$. sericata against promastigotes and amastigotes of $L$. major both under in vitro and in vivo conditions using Balb/c mice as an animal model. This study also examined $\mathrm{IC}_{50}$ of the ES products against $L$. major promastigotes and cytotoxicity of J774A. 1 cells to larval products. To the best of the authors' knowledge, this is the first comparative study dealing with the effects of $L$. sericata crude ES and its fractions on L. major and macrophage cells.

In this study, the highest rate of cytotoxic effects of ES at the highest concentration used were $15 \%, 13 \%$ and $12 \%$ for ES $>10 \mathrm{kDa}, \mathrm{ES}<10 \mathrm{kDa}$ and crude ES, respectively (Figure 4). This result contrasted the 
study by Sanei-Dehkordi et al. in which the cytotoxicity of $L$. sericata larval ES to the same macrophage cell line was reported to be $40 \%$. Although, the ambiguity over the exact concentration of applied ES in their study makes the comparison inappropriate [25]. However, testing L. sericata hemolymph and saliva on the same cell line, [34] reported reduced toxicity to macrophages as in our study[34]. The evaluation of L. sericata and Sarconesiopsis magellanica ES effects on human lung cell line, MRC5, showed that the ES products of the flies had no effects on the survival rates at $10 \mu \mathrm{g} / \mathrm{ml}$ concentration, but they reduced the survival at $20 \mu \mathrm{g} / \mathrm{ml}$ [37]. The toxicity of ES seems to be a function of insect species, rearing methods, ES concentrations and storage conditions, as well as used cell lines.

Larval ES products of $L$. sericata were effective against promastigotes. The crude ES was more lethal than the fractions; ES> $10 \mathrm{kDa}$ and ES $<10 \mathrm{kDa}$. These findings are consistent with other studies in which the effects of ES, hemolymph, and saliva of $L$. sericata larvae were evaluated against $L$. tropica both under in vivo and intro conditions [24,34]. Similar results have been reported by other authors examining promastigote susceptibility to larval ES products $[38,39]$.

The antibiotic properties of $L$. sericata-derived ES were already shown against fungi as well as grampositive and gram-negative bacteria $[40,41]$. In Fact, the ES fractions with molecular weights of $<1 \mathrm{kDa}$ and $3-10 \mathrm{kDa}$ of $L$. sericata have been shown to exert antibacterial activity against gram-positive and gram-negative bacteria including Pseudomonas aeruginosa, Klebsiella pneumoniae and Staphylococcus aureus [42]. The results of this study showed that the ES fraction with molecular weight less than $10 \mathrm{kDa}$, has lower level of anti-leishmanial activity compared with the ES fraction of higher molecular weight (>10 $\mathrm{kDa}$ ). However, the crude ES showed the highest toxicity to L. majorboth under in vitro and in vivo conditions. Therefore, for an effective and strong anti-leishmanial activity, apparently all ES constituents with different molecular weights are necessary.

Susceptibility analysis of intracellular amastigotes of L. major to ES of L. sericata showed that they are more vulnerable to highly concentrated ES than low concentrations. The ES significantly reduced the parasite survival. This finding contrasted those reported by $[25,38]$ using $L$. major and $L$. panamensis amastigotes to infect the macrophage cell line J774 and the U937 cell line respectively. The authors postulated that the applied ES products were more toxic at low concentration that at high concentration. In the present study, the lowest viability percentages of amastigotes were $20.6 \pm 2.7$ and $15.5 \pm 1.1$ which induced by treatments with the crude $\mathrm{ES}(300 \mu \mathrm{g} / \mathrm{ml})$ and glucantime $(100 \mu \mathrm{g} / \mathrm{ml})$ respectively (Table 1 , Figure 5). The survival index values upon treatment with the crude ES were less than those obtained with $\mathrm{ES}>10 \mathrm{kDa}$ and $\mathrm{ES}<10 \mathrm{kDa}$ in amastigote-infected macrophage (J774A.1 cells). Also, a considerable reduction in survival index was seen in the treated cells compared to the control cells (Table 1). It is to note that anti-leishmanial effects of the crude ES and its fractions may be maintained by adjusting their concentrations $[34,43]$. In the present study, parasite load and survival index were determined in vitro and in vivo. In both cases, the lowest parasitic load was induced by the crude ES as well as glucantime. Also, a significant decrease in the parasite load and survival index were observed in groups treated with larval ES products compared to the negative control (Table 1, Figure 7). 
In this study, the crude ES and glucantime performed better in terms of wound size reduction in Balb/c mice infected with $L$. major averaging at $5 \mathrm{~mm}^{2}$ and $4.6 \mathrm{~mm}^{2}$ respectively (Table 2). There was a statistically significant difference in terms of wound size reduction between mice treated with the crude $\mathrm{ES}, \mathrm{ES}>10 \mathrm{kDa}$ and $\mathrm{ES}<10 \mathrm{kDa}$ with those in the negative control. However, no significant difference was observed between Eucerin treated and untreated mice (Figure 6). Using L. sericata maggots directly to treat the lesions of Balb/c mice infected with L. major, [36] failed to record any significant difference between the treated and untreated lesions. This proves that the extracted ES of $L$. sericata larval was more effective than the debridement activity of the larval in healing the leishmanial wounds. The study by Sanei-Dehkordi et al. [25] has confirmed that the ES extracts of $L$. sericata and $C$. vicina larval were highly effective in reducing the lesion size of Balb/c mice infected with $L$. major when compared with the negative control. A similar result was also confirmed the effectiveness of larval ES of L. sericata in healing the leishmanial ulcers of Balb / c mice infected with L. tropica compared to control group $(\mathrm{p}<$ 0.001) [24]. However, another study showed that both maggot therapy and ES derived from L. sericata and $S$. magellanica larvae were similarly effective in treating hamster lesions caused by L. panamensis [28]. The efficacy of $L$. sericata larval ES in reducing the development of the leishmanial lesions was attributed to the substance potency in skewing the monocyte-macrophage differentiation from preinflammatory to pro-angiogenic [44].

Various studies have shown the potential therapeutic effects of larval ES of different flies on Leishmania parasites both under in vitro and in vivo conditions using different species including L. amazonensis [45], L. tropica [24], L. major [25, 36], and L. panamensis [28]. We also clearly showed the anti-leishmanial activity of larval ES of $L$. sericata on the intracellular and extracellular forms of $L$. major parasite both under in vitro and in vivo conditions. We also provided evidence that the larval ES of $L$. sericata has both topical and systemic therapeutic effects on leishmanial lesions of the model animal.

\section{Conclusion}

For the first time in this work, the larval ES of L. sericata were fractionated into 2 substances of different molecular weights; above $10 \mathrm{kDa}$ and below $10 \mathrm{kDa}$. This study showed that both fractions are effective in microscopic and macroscopic evaluation of $L$. major on both intracellular and extracellular forms of the parasite. However, the fraction above $10 \mathrm{kDa}$ had a better effect than the fraction below $10 \mathrm{kDa}$. However, the crude ES showed a higher activity compared to the fractionated ES. This study revealed that L. sericata crude ES and its fractions are effective candidates for curing lesions induced by L. major. However, adding suitable adjuvants may reinforce their effects which requires further studies in the future.

\section{Abbreviations}

CL: Cutaneous leishmaniasis; ES: Excretion and secretion; \%l: Infection percentage; \%DI: Decreased infection percentage; \%V: Viability of amastigote percentage; \%DV: Decreased viability of amastigote percentage; SVI: Survival index; PL: Parasite load. PBS: Phosphate buffered saline; BSA: Bovine serum 
albumin; NNN: Novy-Macneal-Nicolle; FBS: Fetal bovine serum; RPMI: Roswell Park Memorial Institute; DMEM: Dulbecco's Modified Eagle Medium; MTT: 3-(4.5-Dimethylthiazol-2-yl)-2,5-diphenyltetrazolium bromide; DMSO: Dimethyl sulfoxide; IC50: Inhibitory concentration for $50 \%$ of parasite.

\section{Declarations}

\section{Acknowledgements}

The authors would like to thank all staff of the Department of Parasitology and Medical Entomology of Tarbiat Modares University.

\section{Authors' contributions}

All authors of this study were involved in all stages of the research: conceptualization, data analysis, investigation, methodology, and writing.

\section{Funding}

This study was financially supported by Tarbiat Modares University, Tehran, Iran. (Grant no: Grant no: $\mathrm{Med} / 8288)$.

\section{Availability of data and materials}

The data supporting the conclusions of present study is available from the corresponding author on reasonable request.

\section{Ethics approval and consent to participate}

The experimental animal protocols were conducted according to the guidelines of Tarbiat Modares university experimental animal center, Tehran, Iran. The study was approved by the Ethics Committee of Tarbiat Modares University (Approval No. IR.MODARES.REC.1399.124).

\section{Consent for publication}

All authors gave their full consent to the publication of the article

\section{Competing interests}

The authors declare that there is no conflict of interest.

\section{Authors' details:}

Department of Parasitology and Medical Entomology and Vector Control, School of Medical Sciences, Tarbiat Modares University, Jalal AleAhmad Highway, Nasr, P.O.Box: 14115-111, Tehran, Islamic Republic of Iran. 


\section{References}

1. Varotto-Boccazzi I, Epis S, Arnoldi I, Corbett Y, Gabrieli P, Paroni M, et al. Boosting immunity to treat parasitic infections: Asaia bacteria expressing a protein from Wolbachia determine M1 macrophage activation and killing of Leishmania protozoans. Pharmacological Research. 2020;161:105288.

2. Herrera G, Hernández C, Ayala MS, Flórez C, Teherán AA, Ramírez JD. Evaluation of a multilocus sequence typing (MLST) scheme for Leishmania (Viannia) braziliensis and Leishmania (Viannia) panamensis in Colombia. Parasites \& vectors. 2017;10 1:1-10.

3. Monge-Maillo B, López-Vélez R. Therapeutic options for old world cutaneous leishmaniasis and new world cutaneous and mucocutaneous leishmaniasis. Drugs. 2013;73 17:1889-920.

4. Khademvatan S, Salmanzadeh S, Foroutan-Rad M, Bigdeli S, Hedayati-Rad F, Saki J, et al. Spatial distribution and epidemiological features of cutaneous leishmaniasis in southwest of Iran. Alexandria Journal of Medicine. 2017;53 1:93-8.

5. WHO. Control of the leishmaniases. [Online]Available from: http://appswhoint/iris/bitstream/10665/44412/1/WHO. World Health Organization;2010.

6. Fazaeli A, Fouladi B, Sharifi I. Emergence of cutaneous leishmaniasis in a border area at south-east of Iran: an epidemiological survey. Journal of vector borne diseases. 2009;46 1:36.

7. Khajedaluee M, Yazdanpanah MJ, SeyedNozadi S, Fata A, Juya MR, Masoudi MH, et al. Epidemiology of cutaneous leishmaniasis in population covered by Mashhad University of Medical Sciences in 2011. medical journal of mashhad university of medical sciences. 2014;57 4:647-54.

8. Al-Kamel MA. Impact of leishmaniasis in women: a practical review with an update on my ISDsupported initiative to combat leishmaniasis in Yemen (ELYP). International journal of women's dermatology. 2016;2 3:93-101.

9. Singh N, Kumar M, Singh RK. Leishmaniasis: current status of available drugs and new potential drug targets. Asian Pacific journal of tropical medicine. 2012;5 6:485-97.

10. Ouellette M, Drummelsmith J, Papadopoulou B. Leishmaniasis: drugs in the clinic, resistance and new developments. Drug Resistance Updates. 2004;7 4-5:257-66.

11. Omidian M, Jadbabaei M, Omidian E, Omidian Z. The effect of Nd: YAG laser therapy on cutaneous leishmaniasis compared to intralesional meglumine antimoniate. Advances in Dermatology and Allergology/Post $\$ py Dermatologii i Alergologii. 2019;36 2:227.

12. Macêdo CG, Fonseca MYN, Caldeira AD, Castro SP, Pacienza-Lima W, Borsodi MPG, et al. Leishmanicidal activity of Piper marginatum Jacq. from Santarém-PA against Leishmania amazonensis. Experimental parasitology. 2020;210:107847.

13. Sherman RA. Mechanisms of maggot-induced wound healing: what do we know, and where do we go from here? Evidence-Based Complementary and Alternative Medicine. 2014;2014.

14. Sherman RA. Maggot therapy for treating diabetic foot ulcers unresponsive to conventional therapy. Diabetes care. 2003;26 2:446-51. 
15. Zarchi K, Jemec GB. The efficacy of maggot debridement therapy-a review of comparative clinical trials. International wound journal. 2012;9 5:469-77.

16. Courtenay M, Church J, Ryan T. Larva therapy in wound management. Journal of the royal society of medicine. 2000;93 2:72-4.

17. Namias N, Varela EJ, Varas RP, Quintana O, Ward GC. Biodebridement: a case report of maggot therapy for limb salvage after fourth-degree burns. The Journal of burn care \& rehabilitation. 2000;21 3:254-7.

18. Chambers L, Woodrow S, Brown A, Harris P, Phillips D, Hall M, et al. Degradation of extracellular matrix components by defined proteinases from the greenbottle larva Lucilia sericata used for the clinical debridement of non-healing wounds. British Journal of Dermatology. 2003;148 1:14-23.

19. Valachova I, Majtan T, Takac P, Majtan J. Identification and characterisation of different proteases in Lucilia sericata medicinal maggots involved in maggot debridement therapy. Journal of Applied Biomedicine. 2014;12 3:171-7.

20. Sherman RA. Maggot versus conservative debridement therapy for the treatment of pressure ulcers. Wound Repair and regeneration. 2002;10 4:208-14.

21. Sherman RA, Sherman J, Gilead L, Lipo M, Mumcuoglu KY. Maggot debridement therapy in outpatients. Archives of physical medicine and rehabilitation. 2001;82 9:1226-9.

22. Baumann A, Lehmann R, Beckert A, Vilcinskas A, Franta Z. Selection and evaluation of tissue specific reference genes in Lucilia sericata during an immune challenge. PLoS One. 2015;10 8:e0135093.

23. Bexfield A, Bond AE, Roberts EC, Dudley E, Nigam Y, Thomas S, et al. The antibacterial activity against MRSA strains and other bacteria of a< 500 Da fraction from maggot excretions/secretions of Lucilia sericata (Diptera: Calliphoridae). Microbes and Infection. 2008;10 4:325-33.

24. Polat E, Cakan H, Aslan M, Sirekbasan S, Kutlubay Z, Ipek T, et al. Detection of anti-leishmanial effect of the Lucilia sericata larval secretions in vitro and in vivo on Leishmania tropica: first work. Experimental parasitology. 2012;132 2:129-34.

25. Sanei-Dehkordi A, Khamesipour A, Akbarzadeh K, Akhavan AA, Mohammadi AMA, Mohammadi Y, et al. Anti Leishmania activity of Lucilia sericata and Calliphora vicina maggots in laboratory models. Experimental parasitology. 2016;170:59-65.

26. Crosskey R, Lane R. House-flies, blow-flies and their allies (calyptrate Diptera). Medical insects and arachnids: Springer; 1993. p. 403-28.

27. Gasz N, Harvey M. A new method for the production of sterile colonies of Lucilia sericata. Medical and veterinary entomology. 2017;31 3:299-305.

28. Cruz-Saavedra L, Díaz-Roa A, Gaona MA, Cruz ML, Ayala M, Cortés-Vecino JA, et al. The effect of Lucilia sericata-and Sarconesiopsis magellanica-derived larval therapy on Leishmania panamensis. Acta tropica. 2016;164:280-9.

29. Alnaimat SM, Wainwright M, Aladaileh SH. An Initial In vitro Investigation into the Potential Therapeutic Use Of Lucilia sericata Maggot to Control Superficial Fungal Infections. Jordan Journal of Biological Sciences. 2013;6 2. 
30. Mehata AK, Dehari D. Bradford assay as a high-throughput bioanalytical screening method for conforming pathophysiological state of the animal. Journal of Drug Delivery and Therapeutics. 2020;10 1-s:105-10.

31. Varshosaz J, Arbabi B, Pestehchian N, Saberi S, Delavari M. Chitosan-titanium dioxide-glucantime nanoassemblies effects on promastigote and amastigote of Leishmania major. International journal of biological macromolecules. 2018;107:212-21.

32. Garcia AR, Amaral ACF, Azevedo MM, Corte-Real S, Lopes RC, Alviano CS, et al. Cytotoxicity and antiLeishmania amazonensis activity of Citrus sinensis leaf extracts. Pharmaceutical biology. 2017;55 1:1780-6.

33. Haghdoust S, Azizi M, Hoseini MHM, Bandehpour M, Masooleh MM, Yeganeh F. Parasite Burden Measurement in the Leishmania major Infected Mice by Using the Direct Fluorescent Microscopy, Limiting Dilution Assay, and Real-Time PCR Analysis. Iranian Journal of Parasitology. 2020;15 4:576.

34. Rahimi S, Akhavan AA, Rafinejad J, Ahmadkhaniaha R, Bakhtiyari M, Veysi A, et al. The leishmanicidal effect of Lucilia sericata larval saliva and hemolymph on in vitro Leishmania tropica. Parasites \& vectors. 2021;14 1:1-12.

35. Polat E, Kutlubay Z. Four cutaneous leishmaniosis case resistant to meglumine antimoniate treatment. Türkiye Parazitolojii Dergisi. 2014;38 3:177.

36. Kabiri M, Dayer MS, Ghaffarifar F. Therapeutic effects of Lucilia sericata larvae on cutaneous leishmaniasis wounds caused by Leishmania major using BALB/c mice as animal model. J Kerman Univ Med Sci. 2017;24:389-96.

37. Pinilla YT, Patarroyo MA, Velandia ML, Segura NA, Bello FJ. The effects of Sarconesiopsis magellanica larvae (Diptera: Calliphoridae) excretions and secretions on fibroblasts. Acta tropica. 2015;142:26-33.

38. Laverde-Paz MJ, Echeverry MC, Patarroyo MA, Bello FJ. Evaluating the anti-leishmania activity of Lucilia sericata and Sarconesiopsis magellanica blowfly larval excretions/secretions in an in vitro model. Acta tropica. 2018;177:44-50.

39. de Mello TF, Bitencourt HR, Pedroso RB, Aristides SM, Lonardoni MV, Silveira TG. Leishmanicidal activity of synthetic chalcones in Leishmania (Viannia) braziliensis. Experimental Parasitology. 2014;136:27-34.

40. Barnes KM, Gennard DE, Dixon RA. An assessment of the antibacterial activity in larval excretion/secretion of four species of insects recorded in association with corpses, using Lucilia sericata Meigen as the marker species. Bulletin of entomological research. 2010;100 6:635-40.

41. Hassan MI, Amer MS, Hammad KM, Zidan MM. Antimicrobial activity for excretion and secretion of the Greenbottle Fly Larvae Lucilia Sericata (Meigen)(Diptera: Calliphoridae). Journal of the Egyptian Society of Parasitology. 2016;46 1:179-84.

42. Huberman L, Gollop N, Mumcuoglu K, Block C, Galun R. Antibacterial properties of whole body extracts and haemolymph of Lucilia sericata maggots. Journal of wound care. 2007;16 3:123-7. 
43. Tempone AG, de Oliveira CM, Berlinck RG. Current approaches to discover marine antileishmanial natural products. Planta medica. 2011;77 06:572-85.

44. van der Plas MJ, van Dissel JT, Nibbering PH. Maggot secretions skew monocyte-macrophage differentiation away from a pro-inflammatory to a pro-angiogenic type. PloS one. 2009;4 11:e8071.

45. Arrivillaga J, Rodríguez J, Oviedo M. Evaluación preliminar en un modelo animal de la terapia con larvas de Lucilia sericata para el tratamiento de la leishmaniasis cutánea. Biomédica. 2008;28 2:305-10.

\section{Figures}
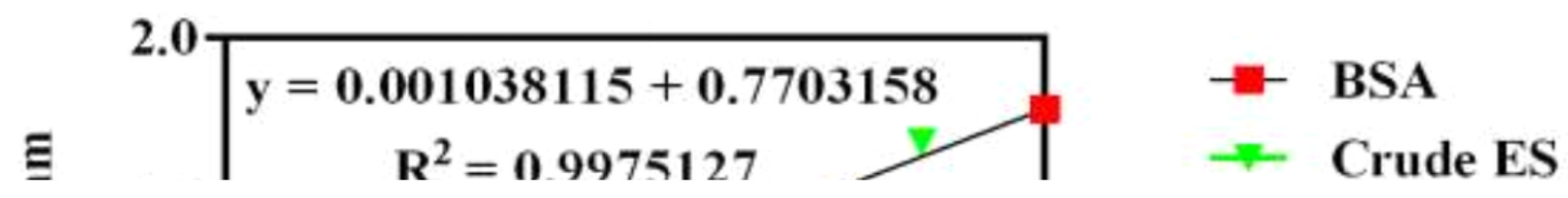

\section{Figure 1}

Bradford assay standard curve and the plotted ES sample concentrations.

政

Figure 2

Dose-response curves of tested ES products of L. sericata larvae and glucantime against L. major promastigotes (IC50) at $24 \mathrm{~h}, 48 \mathrm{~h}$ and $72 \mathrm{~h}$ intervals. 


\section{Figure 3}

Number of survived L. major promastigotes per $\mathrm{ml}$ upon exposure to different concentrations of the crude and fractionated ES at 3 time intervals compared with glucantime (Data presented as Means \pm SD).

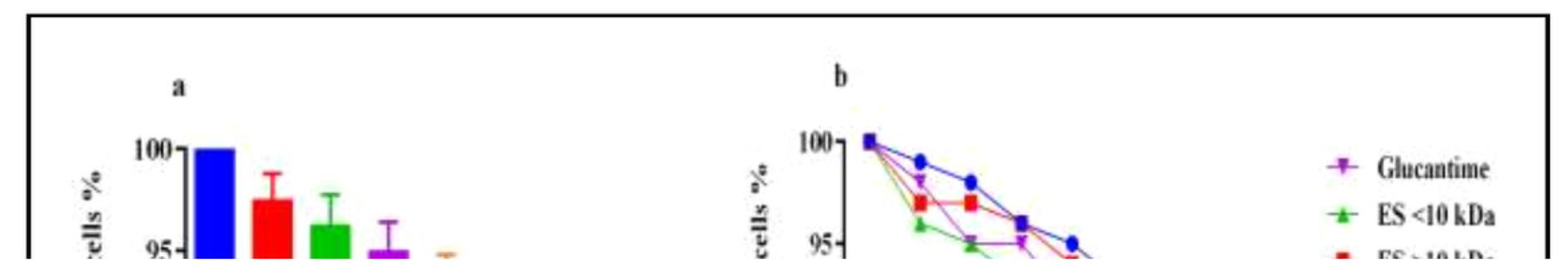

\section{Figure 4}

a: dose-dependent reduction in macrophage viability by the crude ES, b: Macrophage viability reduction exerted by increasing concentrations of the ES products and glucantime.

\section{Figure 5}

Reduction in infection rate and viability of amastigotes upon treatment with the crude and fractionated ES and glucantime.

\section{Figure 6}

Progress of leishmanial lesion sizes in treated and control Balb/c mice followed from pre-intervention stages until 8th week post-treatment.

\section{Figure 7}


Spleen parasitic loads of mice infected with L. major at 8th week post-treatments. (The data present Means \pm SD of triplicates).

\section{Figure 8}

Survival records of treated and untreated mice over a period of 20 weeks post-inoculation with L. major promastigotes.

\section{Supplementary Files}

This is a list of supplementary files associated with this preprint. Click to download.

- ESgraphicalabstract.tif 